\title{
CORRESPONDENCE
}

\section{ORIGIN OF MINOR STRUCTURES ASSOCIATED WITH FOLDING}

Str,--In W. K. Fyson's reply to my letter (Geol. Mag., 1962, xcix, 570-1) it is mistakenly believed that the evidence of the negligible effects of beddingplane drag on confined incompetent layers (Williams, 1961a) is restricted to beds folded between those unchanging in thickness throughout the deformation. However, initially competent layers commonly become incompetent during deformation, for when flexual folding reaches its limit further shortening can only proceed by flattening (de Sitter, 1958; Ramsay, 1962). The arguments $I$ put forward concerning the effects of bedding-plane drag hold for any beds in folds which show a greater amount of thickening and thinning than adjacent ones, although the confining layers may themselves show considerable thickening and thinning.

Fyson implies in his letter that his observations concerning the type of folds I am considering indicate that cleavage is not well developed in the incompetent layers. This is very surprising, for according to my own experience cleavage is usually pronounced, and it appears that the more geometrically deformed the layer the more dominant is the cleavage. However, a detailed investigation is now under way with my colleague Brian Marshall in order to determine if any correlation exists between the degree of fracturing, rotation, and recrystallization of minerals in layers, and the amount of geometrical deformation the layers have received in the folds of the Mathinna Group, which is an interbedded sequence of turbidite sandstones and "normal" mudstones (Williams, 1959), in N.E. Tasmania.

Fyson states that I ignore the role of movement of material parallel to the fold axes during folding in my consideration of the mechanism of formation of minor structures. This is so, and I pointed out the omission in my paper (p. 318, explanation to Text-fig. 1), because I do not consider the arguments presented are affected. I note from Fyson's paper (1962) that he appears to agree !

The mechanism proposed by Fyson (p. 223, Text-fig. 7) for the development of cleavage in incompetent layers appears to be impossible. The flexural slip required is restricted to the competent behaviour of a bed, where there is no change in thickness, whereas the flattening shown is an incompetent phenomenon, which involves the flow of material in the general direction of the axial plane of the fold and must be independent of any previous, or later, competent movements.

When initially competent beds become incompetent during folding due to shortening, fracture cleavage, slaty cleavage, and "drag" folds may result. From a recent study of these minor structures it is evident that they are similar to those developed in confined and incompetent layers, but there are differences in their attitudes with respect to the axial plane of the major fold to which they are related. However, these differences are consistent with an origin similar to that which I propose for the development of the minor structures in confined, incompetent layers.

Finally, it may be pointed out that the "drag" folds discussed recently by Hans Ramberg (1963), and produced so ingeniously in his experiments, are the "parasitic folds" of de Sitter $(1957,1958)$, and are of a flexural origin, although their distribution within a major fold appears to be due to passive transportation filling inter-spaces determined by the thicker competent layers. The "drag " folds referred to above, and discussed in the context of incompetent layers in my paper (1961a), may be termed flow "drag " folds (Williams, 1961b), and have quite a different genesis from those described by Ramberg.

This communication is published by permission of the Department of Mines, Tasmania, Australia. 


\section{REFERENCES}

DE Sitter, L. U., 1957. Cleavage Folding in Relation to Sedimentary Structure. International Geological Congress, 20th Session, Mexico (1956). Section V, 53-64.

1958. Boudins and Parasitic Folds in Relation to Cleavage and Folding. Geol. en Mijnbouw, 20, 277-286.

FYson, W. K., 1962. Tectonic Structures in the Devonian Rocks near Plymouth, Devon. Geol. Mag., 99, 208-226.

Ramberg, H., 1963. Evolution of Drag Folds. Geol. Mag., 100, 97-105.

RAMSAY, J. G., 1962. The Geometry and Mechanics of Formation of "Similar" Type Folds. Jour. Geol., 70, 309-327.

Williams, E., 1959. The Sedimentary Structures of the Upper Scamander Sequence and their Significance. Pap. Proc. Roy. Soc. Tas., 93, 29-32.

1961a. The Deformation of Confined, Incompetent Layers in Folding. Geol. Mag., 98, 317-323.

1961b. Flow Folding in Rocks. Nature, 189, 474-5.

Department of Mines,

EMYR WILlIAMS.

G.P.O. BOX 124B,

HOBART, TASMANia.

22nd July, 1963.

\section{THE STATUS OF THE ORDOVICIAN TRILOBITE GENERA PRIONOCHEILUS AND POLYERES}

SIR,-In 1847, in papers describing the faunas of Ille-et-Vilaine and the district around Rennes, Marie Rouault created two trilobite genera, namely Prionocheilus and Polyeres. Prionocheilus was erected on the basis of a single species, $P$. verneuili Rouault, whilst Polyeres was founded similarly on $P$. dufrenoyi Rouault. Each of these is thus the type-species of the genus by monotypy. Rouault's results constituted part of a larger work and those published by him in 1847 are divided into two small papers, separated by a few lines of discussion and referred to here as Rouault, $1847 a$ and $1847 b$. In the first paper the characteristic features of several trilobites, including Prionocheilus and Polyeres, were tabulated (Rouault, 1847a, table opp. p. 318) but as no species were mentioned these two generic names became available. The second paper again listed the two genera, but this time each was accompanied by a (type) species and briefly diagnosed. There can thus be no doubt of their validity.

Prionocheilus verneuili Rouault $(1847 b$, p. 320, pl. 3, figs. 3, 3a) was described and illustrated from the Middle Ordovician of Poligné, Brittany. In the same year Hawle and Corda $(1847$, p. 88$)$ erected the genus Pharostoma, founded on Calymene pulchra Beyrich, 1846, from the Middle Ordovician of Bohemia. That the two are congeneric is generally agreed, and it has been assumed that Pharostoma takes precedence over Prionocheilus, the differences between the two type-species having been noted by Whittard $(1960$, p. 137) However, in re-describing and figuring the type-material of Prionocheilus vernewili in "Palaeontologia Universalis", Bézier (1907) stated that the genus had priority over Pharostoma, though he gave no detailed reasons for his opinion, which has been generally overlooked. Dr. Alois Prribyl of Prague has kindly informed me (in litt.) that Hawle and Corda's well-known "Prodrom einer monographie der böhmischen trilobiten" was published late in July, 1847. The date of Rouault's 1847 paper has proved more difficult to trace owing to the fact that most copies, including that of the Société géologique de France in Paris, lack the original cover. However, the copy at the British Museum, Bloomsbury, retains the cover and Mr. S. F. Morris has confirmed that the paper was published in April, 1847, as was noted by 